\title{
The Emerging Opportunities for Innovation in Natural Resource-based Industries in Latin America: Only Potential or Being Realised? ${ }^{1}$
}

Eva Dantas, Anabel Marin, Paulo N. Figueiredo, Claudio Bravo-Ortega

\section{Summary}

Increasing innovation opportunities in natural resources industries are transforming these industries, making them more dynamic and useful platforms for development. Lat-

in American countries show a mixed record in exploiting these new opportunities.

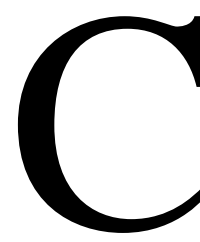

OUNTRIES THAT ARE RICH IN NATURAL RESOURCES AND LOW AND middle income countries, among them prominently Latin American countries (LAC), continuously face a supposed dilemma: whether they should embrace a natural resource-based specialization route or diversify away from natural resources (NRs). In the past, the choice has tilted heavily towards the latter, with LACs going to great lengths to foster manufacturing sectors through an import substitution strategy at the expense of their traditional resource sectors. Following the commodity boom of the early 2000s and the increased commodity dependence of NR-rich countries, the question is once again high in the policy debate.

\footnotetext{
1 This policy brief is the result of the research project entitled 'Innovation Capability Building, Learning and Institutional Frameworks in Latin American Countries ' (LACS) Natural Resource Processing Industries: Experiences from Argentina, Brazil and Chile', sponsored by the International Development Research Centre (IDRC) (IDRC Ref. 105161-001) and executed by the Getulio Vargas Foundation (FGV), under the leadership of Paulo N. Figueiredo. The views expressed herein are solely those of the authors and do not represent the views of IDRC or FGV. The complete findings of the research project are presented in the documents cited in endnotes 11 and 12.
} 
There are strong signs that resourcerich low and middle income countries everywhere will continue to try and turn away from their natural advantages and encourage investment in unrelated manufacturing sectors. In the summer of 2010 the then Russia's president Dmitri Medvedev settled a strategic partnership in the area of high technologies such as space technologies, nuclear and nanotechnology. Russia has expressed its will to move from the traditional industrial activities based on NRs towards 'highly advanced technology and cutting edge innovation activities'. To meet this goal, president Medvedev focused on project Skolkovo Institute, a large technological project, meant to be Russia's Silicon Valley. ${ }^{2}$ President Vladimir Puttin is supportive to the initiative by arguing that Russia must diversify away from its dependence on NRs and move towards 'high-tech' industries. Such a black-and-white policy choice reflects the long held conventional wisdom on the relationship between NRs and development. This involves a simple dichotomy where NRs are seen as non-conductive to industrial and economic growth and 'hightech' industries the only way to it.

However, both historical evidence and recent understanding have questioned this simplistic dichotomy.
History abounds with negative experiences of countries trying to use hightech industries to encourage processes of sustained growth and development without much success (e.g. Guatemala, Honduras, El Salvador) and with positive experiences of countries that have been able to use their NRs as an engine for growth and development (e.g. USA, Canada, Australia, Norway, Sweden, and Finland). In short, the bottom line is: there seems to be no inevitability on the way that the exploitation of NRs (or other productive activity) affects growth, either negatively or positively. What seems to differ in triggering a vicious or virtuous circle are the internal policy responses to deal with the risks and potentialities of NRs.

The reliance on NRs can foster economic development when underpinned by efforts to increase technological innovation and the concomitant accumulation of capabilities to innovate around these resources. ${ }^{3}$ The exploitation of NR wealth becomes a viable path for development when complemented with investments in skills, learning, knowledge, education, and innovation capabilities. Indeed, when combined with innovation efforts and technological dynamism, NRs activities can provide the scope for: 
- Productivity growth comparable to manufacturing;

- Increased competitiveness visà-vis producing countries with much lower wages;

- Increases in the endowments of NR themselves. For instance, oil and mineral reserves increase with the application of advanced exploration and production techniques; and

- Diversification towards related higher value products and activities from a strong NR base.

This new understanding matters for policymakers in LACs because recent changes in world conditions provide resource-rich countries with a new 'window of opportunity' to use NR abundance to fuel growth and development. ${ }^{4}$ In this policy brief we will show that, as Latin American economies are ever more dependent on NRs, recent changes in the demand for NRs, and in related knowledge bases, are creating increasing innovation opportunities for these industries which put into question conventional views on NRs as non-dynamic and inappropriate for development.

By drawing on insights from original research on three sectors (biofuels, forestry, pulp and paper, and seeds) in Argentina,
Brazil and Chile during the period 1980-2010, we will demonstrate that the ability to exploit these new innovation opportunities has been, however, heterogeneous across these countries, industrial sectors and firms. We will offer a few proposals for a policy agenda for LACs to take advantage of new demand conditions and innovation opportunities in NRs sectors and improve their mixed records in exploiting the new opportunities.

\section{Latin American countries:}

\section{'uncomfortably dependent' on NRs?}

LACs have historically been and still are heavily dependent on NRs. By the mid-20th century more than $90 \%$ of the exports of the region were related to NRs. Governments in Latin America spent part of the last century trying to reduce this dependency through the application of what were known as import substitution industrialization (ISI) policies (state-induced industrialization through subsidization of vital industries, highly protectionist trade policies, subsidized credit and the creation of an internal market). These policies managed to create a manufacturing sector in the region, with different degrees of success across countries. However, as a whole they did not succeed in reducing substantially the dependency of the region on NRs. 
By the 1970s, the share of exports which were NRs or very related to NRs was still $80 \%$ and in the 2000 s this share is still $70 \%$ (see Table 1 ).

Table 1. Share of NRs and rate of GDP growth

\begin{tabular}{l|c|c}
\hline \multicolumn{1}{c|}{ Region } & $\begin{array}{c}\text { \% of NR exports } \\
\text { over total ex- } \\
\text { ports(2000s) }\end{array}$ & $\begin{array}{c}\text { Rate of GDP growth } \\
\text { (1970-2008) }\end{array}$ \\
\hline Latin America & $\mathbf{7 0}$ & 1.64 \\
\hline $\begin{array}{l}\text { Producers of NRs, developed } \\
\text { economies }\end{array}$ & 59 & 2.29 \\
\hline Developing economies in Asia & 30 & 4.77 \\
\hline $\begin{array}{l}\text { Mature economies } \\
\text { Source: Cimoli, M. and Porcile, G. (2011). Learning, Technological Capabilities and Structural Dynamics, in Ocampo, J.A. and Ros, J., The } \\
\text { oxford Handbook of Latin American Economics, Oxford University Press. }\end{array}$
\end{tabular}

This share is high even compared with other countries specialized in NRs such as Australia and Canada, whose share of NRs exports are around $59 \%$. This is even higher when compared with other developing economies in Asia, which have reduced their share of NRs exports from $94 \%$, in the 1960 s, to $30 \%$ nowadays. In addition, Latin America's reliance on exports of NRs (the share of raw NRs only) has increased by $10 \%$ over the last 15 years (see Figure 1 ).

But how heterogeneous is the dependence on NRs across Latin American and high income countries?
Among developed countries with relative abundance of NRs, the degree of dependence on NRs exports varies considerably. While the shares of NRs in Norway's and Australia's exports are above $80 \%$, for Sweden, Finland, and Denmark those shares are between $20 \%$ and $40 \%$. Such variation does not occur across the more developed countries in Latin America, namely Argentina, Brazil and Chile, which are uniformly more dependent on NRs exports, all having shares higher than $60 \%$ (see Figure 2). 


\section{FGV}

EBAPE

Figure 1. NRs and manufacturing exports for LACs and high income countries

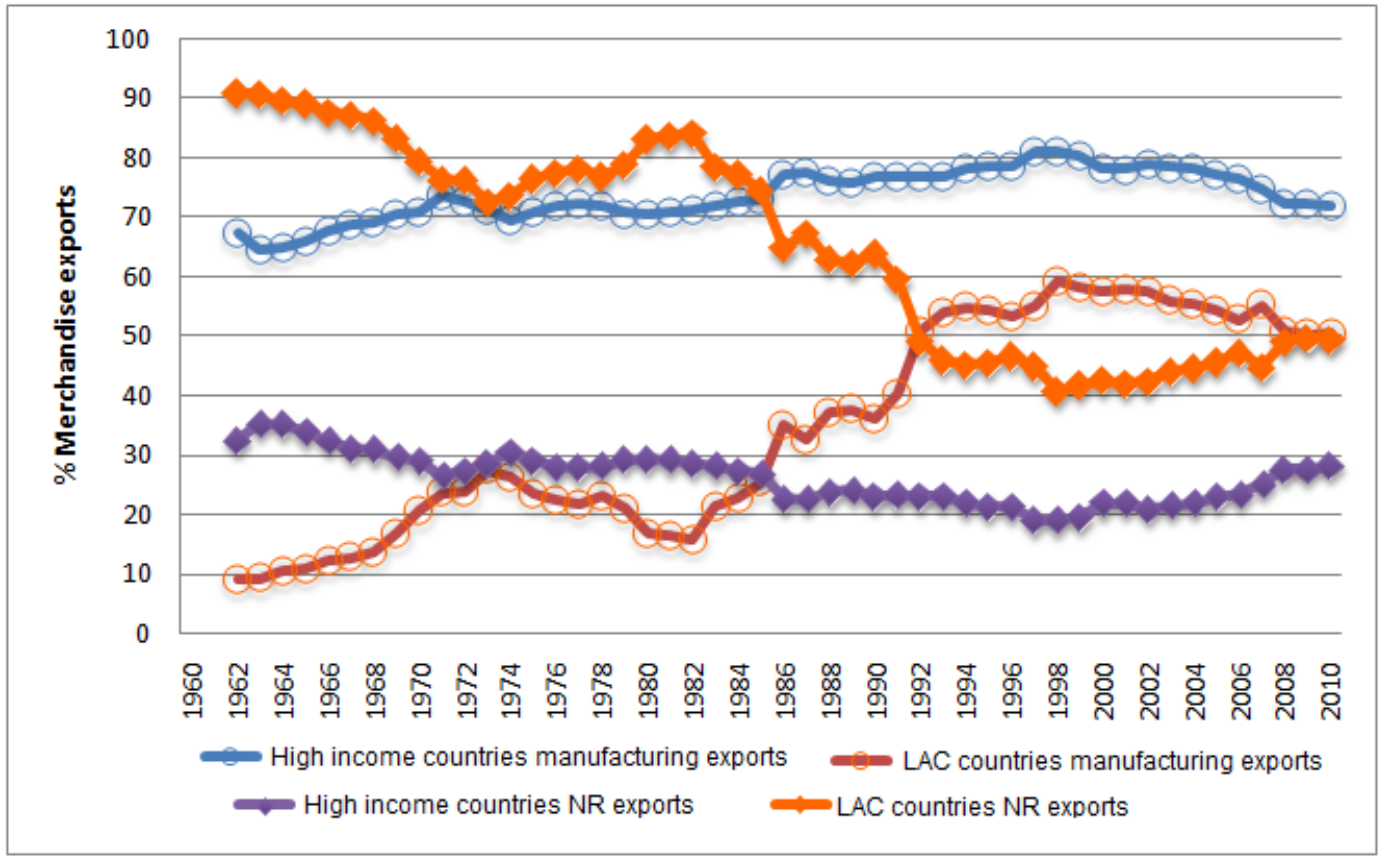

Source: World Development Indicators, World Bank (2012)

Figure 2. Share of NRs exports for selected countries

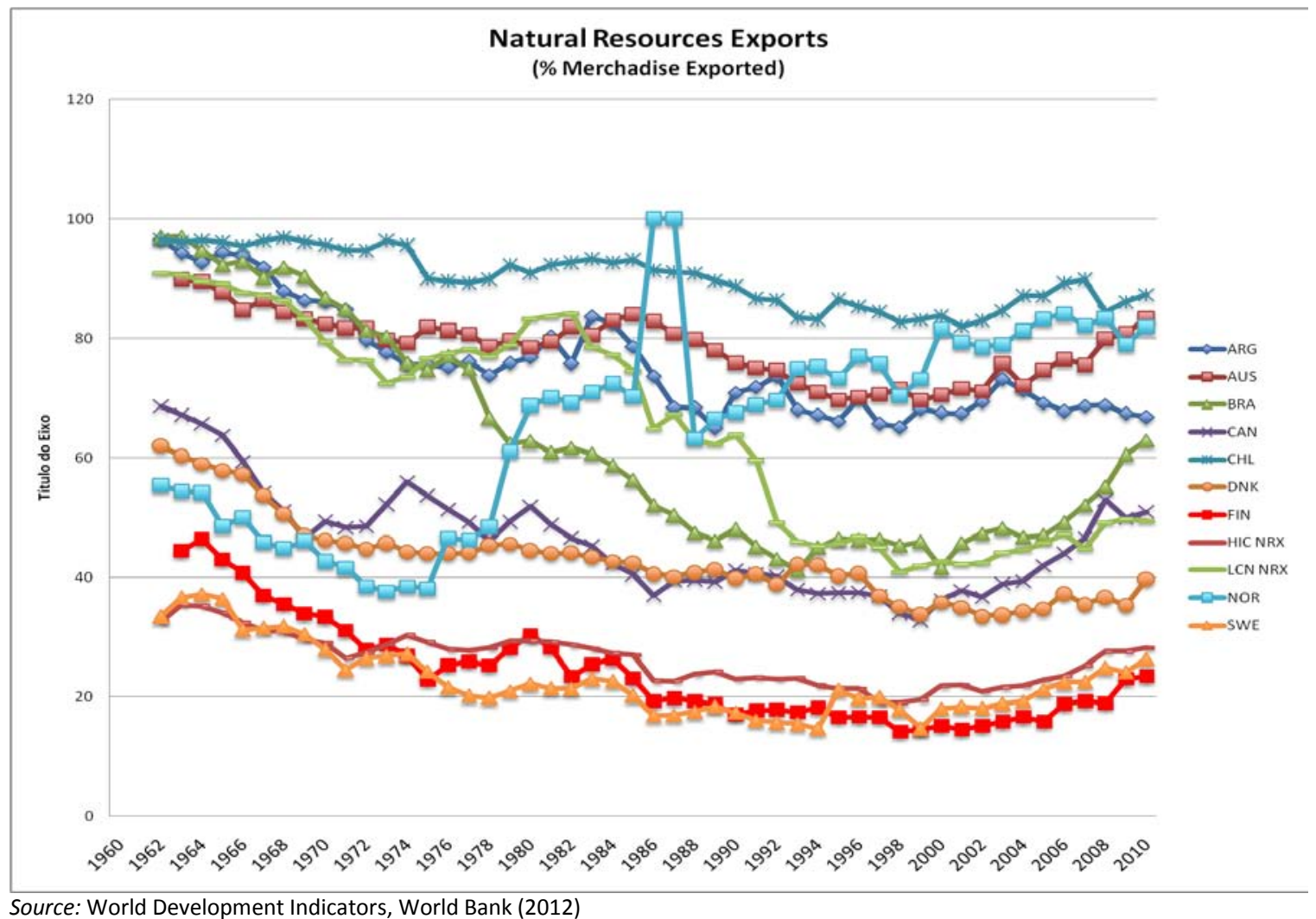


A further illustration of how 'uncomfortably dependent' Latin American countries may be on $\mathrm{NRs}^{5}$ is provided by their share of tax revenues from NRs in the total tax incomes (see Figure 3). Venezuela, Ecuador, Mexico and Bolivia are the most reliant on NRs tax revenues, with a share between $30 \%$ for Bolivia and $50 \%$ for Venezuela. Then, we have Chile with $20 \%$, and Argentina and Colombia with around $10 \%$. The average for the region is $30 \%$.

\section{New innovation opportunities in NRs: what is left of the resource curse?}

This kind of dependency on NRs has attracted the attention of economists since Adam Smith's time. However, it was not until the 1950s that this issue became central to the development agenda. At that time, economists associated to the then Economic Commission for Latin America (ECLA), preoccupied with the poor economic performance of Latin American and

Figure 3. Tax revenues from NRs (as \% of total tax revenue)

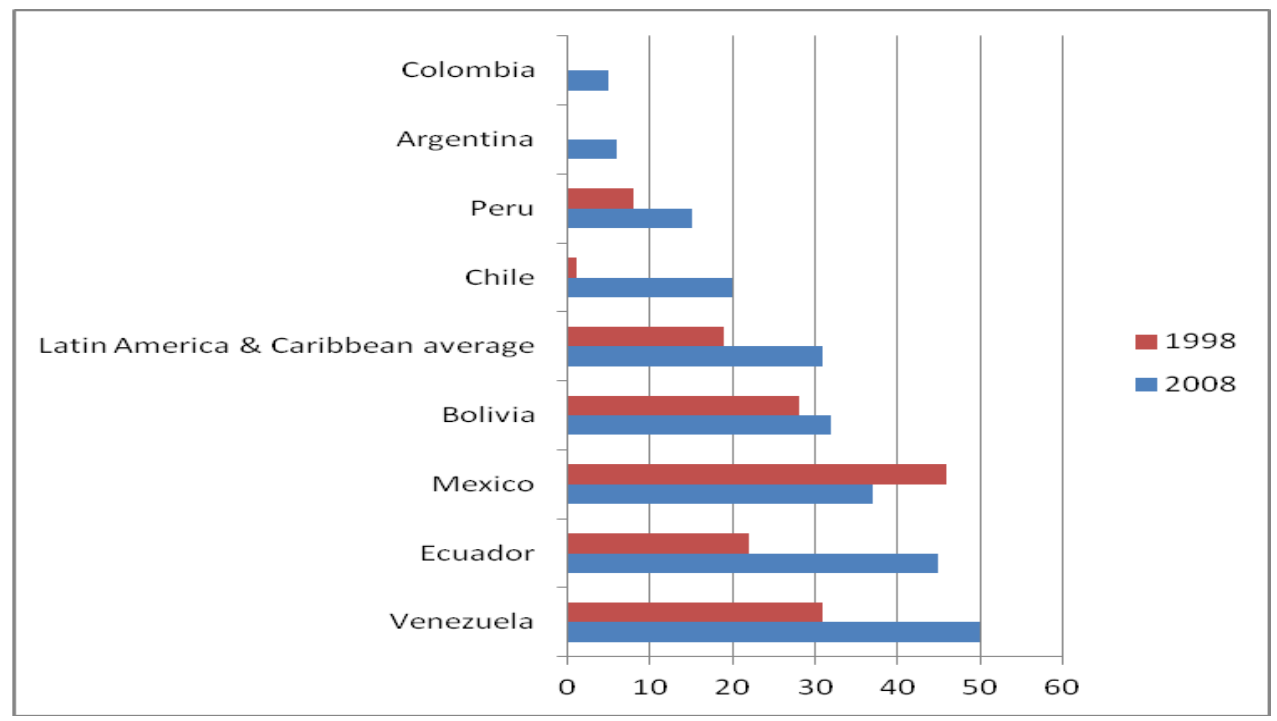

Source: World Bank/de la Torre, A., Sinnott, E. and Nash, J. (2010) Natural resources in Latin America and the Caribbean: beyond booms and busts? The World Bank. Washington, DC.

Note: For Argentina, data are for export taxes only; for Colombia, the 2000-2005 average for hydrocarbon tax revenues.

What is more striking is the evolution of the share of tax revenue coming from NRs between 1998 and 2008. During this period all countries, except Mexico, increased their dependency on NRs. In Venezuela the share went from around $30 \%$ to almost $50 \%$, while in Chile it increased from being negligible to around $20 \%$.
African countries, reacted to mainstream economics' prescriptions for these countries to specialise in NRs to take advantage of their resource abundance. The objection was based on the following reasons: 
- Natural resources activities were believed to face several types of demand and supply constraints, all of which would explain a continuous downward trend in the relative price of primary commodities in relation manufactures. ${ }^{6}$ The demand for NRs would rise less than proportionately to increases in income. Thus, countries heavily specialised in NRs would not benefit from increases in world demand associated with world income growth. Additionally, their demand growth was slower than that for manufactures, because technological progress in the manufacturing sector tends to be raw materials saving.

Regarding supply, NRs were not favoured by technological progress and its associated dynamism. Besides, the little technological progress occurring did not translate into larger demand or greater profits but in reduced prices, benefiting consumers in foreign countries and not producers in developing countries.
- There was the high instability of export prices of commodities. Countries that relied heavily on commodity exports would therefore be very vulnerable to constant fluctuations which would affect their economy not only via abrupt changes in tax revenues but also via changes in the exchange rate and local investments.

- A third set of problems was the particular way in which NRs activities were organised in developing countries. In these countries, NR activities were typically dominated by multinational corporations, which, as it used to be argued, repatriated the benefits and did not invest locally. This also meant that the local development of backward and forward linkages was very limited, closing off the main way in which the emergence of any activity could contribute to development. ${ }^{7}$

Since the 1990s those concerns have been reinvigorated by the observation that there seems to be a negative association between resource abundance or specialisation and growth. ${ }^{8}$ This is explained in part by the so called Dutch Disease. 
The so-called Dutch Disease involves the appreciation of the real exchange rate caused by the rise in commodity exports, leading to a contraction of the tradable sector and the tendency of a booming resource sector to draw capital and labour away from a country's manufacturing sector, thus raising production costs.

Based on these ideas, policy approaches in Latin America have consistently aimed to change the productive structure of the economies away from NRs. Resource-based activities have been heavily taxed or have been left unattended. Most of the policy efforts have been oriented to support industries that supposedly have a higher potential to contribute to development. Early on, favoured industries were any within the manufacturing sector, whereas nowadays the support is geared towards specific types of manufacturing industries identified as 'high-tech' by the Organisation for Economic Co-operation and Development (OECD).

\section{New evidence, new opportunities: questioning the negative views}

Some of the conventional negative assumptions about NRs, however, have been challenged. For instance, the Dutch Disease may be less common in developing countries, where resources are normally unemployed and therefore the costs of alternatives to forgo are lower. A measurement problem seems to explain the negative association between NR abundance and growth found in empirical studies. By simply replacing the absolute measure of resource abundance used (NR exports as a share of GDP) by a relative measure (net exports of NRintensive commodities per worker), the negative association is not observed and this association can turn positive if measures of human capital are considered. $^{9}$

Indeed, many of the observed negative effects of NR that may have been valid in the past have ceased to be relevant over the last decades. This is because technological change and altered demand substantially transform the context and the conditions under which industries operate. Thus, unquestionable facts just a few decades ago may have changed significantly over time, ${ }^{10}$ as follows: 
- The rise of Asia and the incorporation to the market system of the socalled 'Second World' have accelerated the rhythm of growth in demand for energy, food and raw materials to the point of straining the limits of resources. This has led to the expectation of rising prices and widening the opportunities for higher investments in innovation in the production of NRs.

- Changes in consumer tastes, market requirements, as well as environmental and social concerns have opened opportunities for the development of a wide array of products and services based on the exploitation of NRs, including more sustainable patterns, which were virtually non-existent before. Consequently, products derived from NRs are no longer necessarily only 'commodities'. Some examples of this process of 'decommoditisation' and search for more sustainable paths include organic food, fair trade wine or coffee, sustainably certified forestry and marine products, seeds enhanced with nutrients, and planted forestry.

- Advances in scientific disciplines connected to NRs have widened the opportunity space for incorporating new knowledge in production. As a result, producers are massively incorporating new technologies, such as information and communication technologies (ICTs), biotechnology, nanotechnology and new materials in the extraction and transformation of NRs. These innovations are broadening the knowledge base of the industry. Therefore, NRs activities can now hardly be considered simply 'low-tech'.

- An excellent example is that of the seed industry, which has become highly knowledge intensive during the past twenty years or so.

- Global corporations of NRs are increasingly using decentralised forms of production and innovation. They commonly weave networks of innovation upstream and downstream as well as laterally from the NR base, including local producers, universities, etc. Thus, the model of exploitation of NRs based on 'foreign enclaves', i.e. foreign-owned companies with limited local engagement, is becoming less and less viable. The mining industry provides an example of this transformation. This industry has shifted from being highly integrated to de-integrated, with key knowledge services being now outsourced and leading to the emergence of a new sector of specialised knowledge-intensive mining services providers (SKIMS), often involving local companies. 
In line with these new trends, very up-todate evidence from LACs indicates that NR-based and -related industries carry new opportunities for innovation and dynamism that did not exist in the past ${ }^{11}$ :

- In Argentina, Brazil and Chile, an industry's association to NRs either as a consumer industry (e.g., pulp and paper and mineral industries) or as a supplier industry (e.g., agricultural machinery) has a positive impact on technological opportunities.

- Strikingly, in Brazil and Chile, NRs consumer industries have higher technological opportunities than any other kind of industry;

- In Argentina, both consumer and supplier industries of NRs display higher innovation opportunities.

- So much so, that the popular OECD classification of industries as high-, medium- or low-tech - which is very often taken as an indication of innovation opportunities - does not reflect the realities observed in LACs.

- In this region, several of the low- and medium-tech industries in the OECD's classification, such as pulp and paper, food, metals and non-metallic minerals are high-tech - or have high innovation opportunities.

- Similarly, in the other way round, several of the industries typically classified as high- or medium high-tech by the OECD (e.g., TV and communication equipment, electronic equipment and components) are low-tech in LACs.
But to what extent are LACs exploiting these new innovation opportunities in NRs industries?

The extent to which firms in NRs sectors, such as seeds, forestry, pulp and paper, and biofuels in Argentina, Brazil and Chile are exploiting these new innovation opportunities varies considerably not only across country and sectors, but also across firms within a particular country and sector (see Figure 4). ${ }^{12}$

A number of firms in the forestry, pulp and paper sector in Brazil and Chile, in the seed sector in Argentina, Brazil and Chile, and in the biofuels sector in Brazil and Chile have become highly able to take advantage of new innovation opportunities by developing R\&D-based advanced and world-leading innovation capabilities. In stark contrast, firms in the forestry, pulp and paper sector in Argentina and in the biofuel sector in Brazil and Argentina are missing the chance to exploit new innovation opportunities in NRs because they have been unable to move beyond a limited level of innovation capabilities (basic to intermediate) based on minor changes and adaptations of technologies. 
But even in sectors in which a number of firms have been highly able to exploit innovation opportunities, other firms still lag behind in lower levels of capabilities. These firms are missing the innovation opportunities around them.

Figure 4. Mixed results in making use of new innovation opportunities in NRs in Argentina, Brazil and Chile

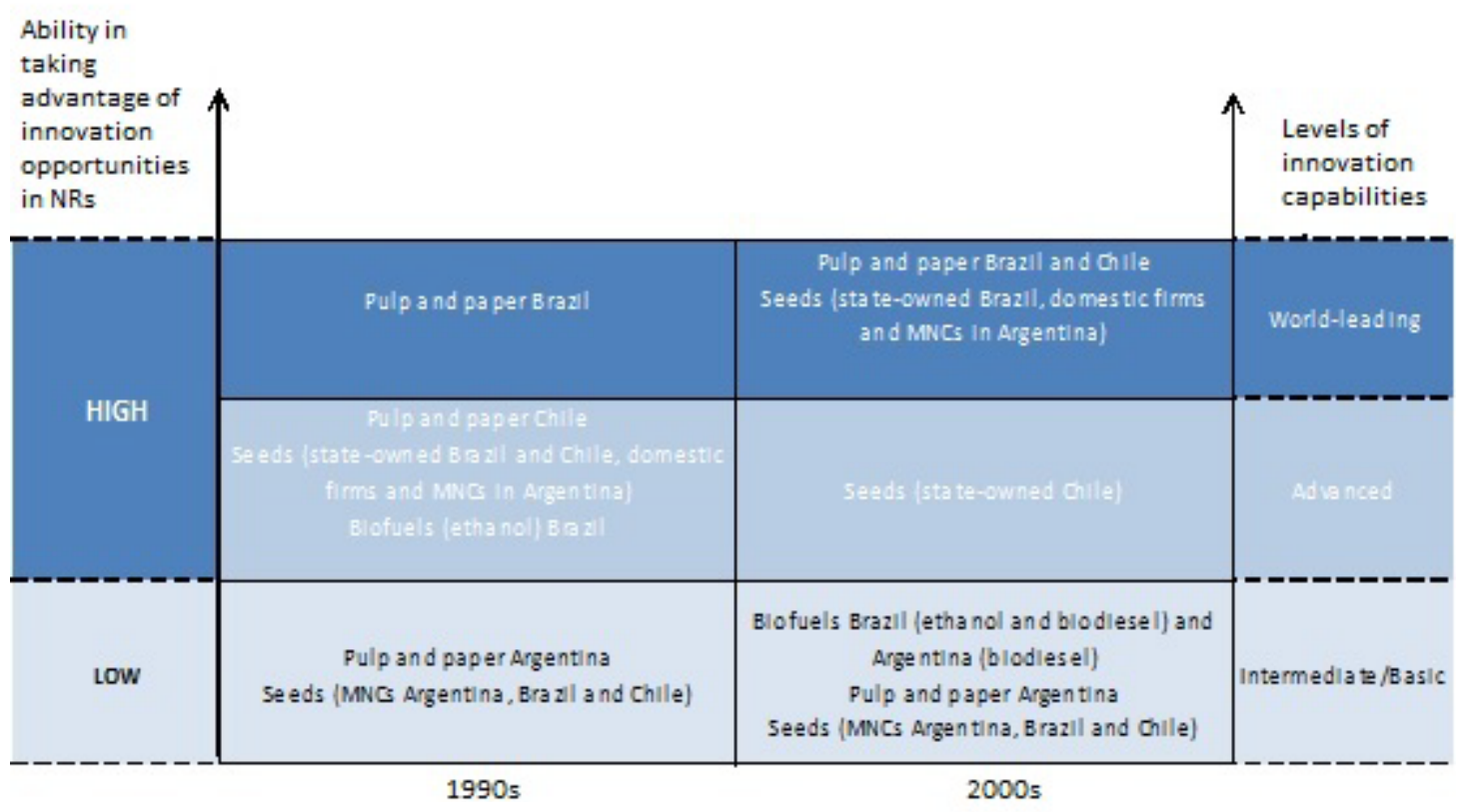

Making the most of new innovation opportunities

Contradicting most expectations, some domestic firms in the seeds industry in Argentina, Brazil and Chile are building world-leading innovation capabilities and making the most of opening innovation opportunities. They have been undertaking R\&D in genomics, in second wave genetically modified seeds, and opening new directions for innovation in the sector. Key firms have been undertaking substantial R\&D efforts at the innovation frontier supported by sophisticated biotechnology techniques such as genetic engineering and molecular biology to generate new-to-the-world genetic material and agricultural processes. And they have managed to obtain concrete innovative outputs in association with these efforts.

World-leading innovation efforts are not all related to the use of transgenesis for the improvement of seeds. The more innovative firms, in effect, are responding to the new opportunities by directing their innovative efforts in more than one direction, besides transgenesis, including advanced methods of conventional breeding and non-transgenic genetic modification. 
For example, the Argentine firm Bioceres has several programmes in molecular breeding, and Nidera is committed to the use and development of mutagenesis as an alternative to transgensesis in several of its main programmes, and the Brazilian organisation Embrapa has engaged substantial resources to the support of research in non-genetically modified (GM) soybean seeds.

Some pulp and paper firms in Brazil and Chile have also developed worldleading innovation capabilities. Indeed, Brazilian firms took the lead in seizing an opportunity to innovate in the pulp and paper industry along a new technological trajectory (see Box 1).
By the late 1990s, Chilean firms had caught up with the Brazilian ones. During the 2000s leading firms in Brazil and Chile engaged in R\&D to develop new genetic materials and cutting-edge forestry production. Since then, they have implemented world-leading R\&D in the genetic transformation of eucalyptus based on nationwide research networks (e.g., the Genolyptus Project in Brazil.)

\section{Box 1. Taking opportunities in NRs to become a global innovator: the pulp and paper industry in Brazil}

The experience of leading firms of Brazil's pulp and paper industry is an example of taking advantage of an opportunity to undertake world-leading innovation and achieve international leadership [(e.g., Suzano, Klabin, Fibria (former Aracruz and Votorantim)]. Until the mid-1960s, paper produced by the world's leading firms in the US, Canada and Nordic countries was made from long-fibre pulp derived from conifers. Those leading incumbents continued to develop that technological trajectory, but as early as the 1960s, several paper producers in Brazil shifted to production based on short-fibre pulp derived from eucalyptus - a source of pulp with great potential in Brazil and compatible with Brazil's environmental conditions. This innovation involved the original development of new eucalyptus varieties which were more productive and more resistant to disease. In parallel, it involved the development of modified process technology that was installed in a succession of new plants over three decades. Specifically, the firms took a different direction of technological development from those already pursued by the global industry leaders. By so doing, they opened up a qualitatively different segment at the international technological frontier. By engaging in original $R \& D$ based on advanced biotechnology methods, and, more recently, nanotechnology, these Brazilian firms established, since the 1990s, a worldwide leadership in what has become a new, technologically differentiated segment of the global paper industry. 
Companies in Brazil and Chile have been drawing on their innovation capability in feedstock to open up new business and innovation opportunities and diversify into new industrial activities. This diversification has involved the entry into electricity and steam generation, biotechnology, phytotherapics and phytocosmetics, and emerging activities, such as lignocelulosic biofuels and biorefineries, especially in Brazil. ${ }^{13}$

The embryonic biofuels sector in Chile also offers examples of efforts to exploit the new opportunities for innovation in NR activities, by investing in new 'generations' of biofuels. One of them refers to a Chilean consortium which is taking advantage of a new window of opportunity and entering the industry based on an emerging technological trajectory centred on algae-based biofuels production.

The organization is undertaking world-leading R\&D activities on algae biofuels. Yet, these efforts have not reached the commercialization stage.

\section{$>$ Failing to exploit new innova- tion opportunities}

Firms in the Argentine and Brazilian biofuels industry are not taking advantage of the new opportunities to innovate. Most firms in Argentina and Brazil have not moved beyond a basic to intermediate level of innovation capabilities, based on minor and incremental changes in existing technologies, with ethanol firms in Brazil remaining at such level for over two decades.

A large Brazilian ethanol firm even attained an R\&D-based advanced level of innovation capabilities, but subsequently regressed to and remained at an intermediate level. Although in the biofuels sector in Brazil some R\&D activities are undertaken by an industry-funded research centre, the Sugarcane Technological Centre (CTC), which works as an external $R \& D$ arrangement, and other research institutes and universities involved in biofuels research, intra-firm innovative efforts have been limited.

Similarly, in the pulp and paper industry in Argentina firms have not moved beyond the lowest level of technological capabilities.

One case also shows a deterioration of capabilities with the firm losing some of those which had been developed earlier. Even in sectors where a number of firms have managed to build advanced to world-leading capabilities, there are considerable differences in firms' capabilities with some of them remaining at lower levels. For instance, in the Argentine, Brazilian and Chilean seeds industry there are firms which are not progressing to advanced and worldleading innovation capabilities. 
Notably, with respect to the seeds industry, subsidiaries of multinational corporations (MNCs) in Argentina (with one notable exception), Brazil and Chile are in a less advanced position, when compared to domestic firms, in terms of developing innovation capabilities. They draw most of their technological assets from their corporations and are undertaking very little innovation in the region, limiting their local R\&D to efforts to perform adaptations to the local context.

Similarly, not all domestic firms in the seeds industry are fully developing advanced or world-leading innovation capabilities. Some domestic firms in Argentina and Brazil do not perform $R \& D$ oriented to the identification of genes, despite selling mostly transgenic seeds. They typically develop varieties adapted to the local conditions, buying biotechnology events (or genes) from other firms (e.g., MNCs) and pasting them to their varieties through conventional breeding techniques.

How do innovative firms build up capabilities to make good use of innovation opportunities in NRs in contrast with less innovative ones?

World-leading and advanced innovators engage in a larger number of learning mechanisms (or mechanisms for acquiring and creating knowledge to build innovation capabilities) in comparison with less innovative firms, as follows:
- They interact with a higher diversity of actors to acquire knowledge located outside their boundaries. For instance, in the seed sector in Argentina, Brazil and Chile, they tend to perform their main innovation tasks and learning efforts closely interacting with the four main sources of knowledge: (i) users: multipliers, farmers and/or trading firms; (ii) suppliers; (iii) universities and public research institutes; and (iv) other firms in the sector: owners of biotechnological events and varieties; and competitors. They also use more advanced forms of cooperation, such as joint R\&D, which involve bi-directional flows of knowledge. They are also often engaged, via these interactions, in the creation of new knowledge as well as in the use of existing knowledge. In contrast, less innovative firms mostly interact with competitors and users, using less advanced forms of co-operation, such as licensing. They do not engage in interactions to create new knowledge.

- World-leading and advanced innovators carry out more intense efforts internally to absorb and assimilate the knowledge acquired from external sources and transform such knowledge into new technologies, new products and new processes. They engage in substantial efforts to increase the intensity of internal training, R\&D experimentation, and efforts to share and codify the knowledge acquired externally and internally. 
For instance, in the forestry, pulp and paper industry in Brazil and Chile, firms gave great emphasis to the organizational formalization of their R\&D activities. Firms with less advanced innovation capability levels were passive in this respect using a narrower range of learning mechanisms.

\section{A policy agenda to take advantage of new demand conditions and innova- tion opportunities in natural resources sectors}

The changes in demand conditions and innovation opportunities in NR-based and related sectors, which were highlighted above, call for a new approach to policy to foster technological innovation in these sectors. In this respect, one way forward represents the abandonment of conventional policy approaches to NRs that have been proved to be ill-advised.

In this context, policymakers should avoid concentrating most of their efforts in trying to diversify away from NRs and towards unrelated high technology industries, not based on current comparative advantages. Furthermore, it is important to avoid neglecting the NRs sectors themselves, treating the question of "how to support the technological dynamism of NRs sectors" as a non-policy issue that never enters the policy agenda. Letting nature, almost literally, to take its course will certainly lead to missing again the opportunities offered by a NR-driven development path.
But mostly important, a second way forward demands the advancement of a new agenda of positive policy initiatives to take advantage of the new demand and technological conditions and increase the technological dynamism of NR sectors. Moving towards such an agenda, four sets of actions seem important to be considered:

Initiatives to support the strengthening of innovative efforts in NR-based sectors;

Initiatives to foster diversification upstream, downstream and laterally or horizontally from a NR base;

Initiatives to support human capital development by creating a critical mass of highlyqualified and competent managers, engineers, technicians and civil servants;

Initiatives to assist domestic firms in complying with intellectual property rights (IPR) regulations and strengthen IPR protection of local efforts.

Below, we comment on each of these four recommended actions. 
* Initiatives to support the accumulation of innovation capabilities in NR-based and related sectors

These should include a varied set of incentives to stimulate innovative efforts and the accumulation of innovation capabilities in the complete innovation system associated to given NRs which dominate an economy. To lead to innovation, i.e. the operational introduction of new or improved products and processes, marketing and organisational methods in an economy, incentives should cover the broad range of innovative activities that compose the whole process of innovation, much more than just research, or even research and development (R\&D). Therefore, policy initiatives should avoid privileging some elements of the innovation process, such as research, at the detriment of others, such as development, trial production, scaling up, design, tooling up and industrial engineering, without which innovation outcomes cannot be reached.

Mechanisms to support the accumulation of innovative capabilities and innovation need to consider all types of organisations in the relevant innovation system, namely firms, universities, research institutes, technology institutes, technical training centres etc, whose innovative efforts are necessary for innovation to occur.
But incentives to foster the accumulation of innovation capabilities of firms should receive the highest importance, since they are responsible for the ultimate transformation of knowledge into improved or new products.

Without firms' effective involvement in innovative efforts, it is hardly possible to innovate in the sense of introducing new commercial applications that contribute to the generation of wealth.

The initiatives geared towards the accumulation of innovation capabilities in firms may follow a two-pronged path. The first path is concerned with fostering the increase of innovative efforts of existing firms. To be effective, policy incentives should be tailored and appropriate to the current levels of capabilities of existing firms. Actions should be centred, on the one hand, in providing support for firms in solving technical problems they face at their present technological activities. On the other hand, they should also create incentives for firms to shift towards more complex technological efforts. The second path involves mechanisms to stimulate the creation of new innovating firms. This will demand programmes to support spinoffs and start-ups derived from emerging technologies and products, and entry of new learning-eager firms in established markets. 
* Initiatives to support diversification upstream, downstream and laterally or horizontally from a NR base

This requires actions to identify emerging sectors that can add value to the existing NR base, having as a starting point the leading NR sectors within a given economy.

This can be underpinned by 'selfdiscovery' activities, ${ }^{14}$ i.e. scouting for investment opportunities in emerging NR-related industries and potential new products that may be profitable. Such effort should involve different stakeholders, including existing firms, since they possess the information about the obstacles and potentialities associated to exploiting emerging opportunities.

This exercise should provide the foundation for devising policy mechanisms to support the development of productive activities which are linked to the NR base in three different ways, through: (i) forward linkages (processing and beneficiating industries, packaging, marketing and distribution); (ii) backward linkages (production of inputs, capital goods, and business services); and (iii) horizontal/lateral linkages (supply of inputs originally to NR sectors, subsequently spilling over to applications in other sectors).
Therefore, policy initiatives should focus on the complete innovation system connected to a given NR base. Centrally important are efforts to increase synergy and coordination between policy initiatives supporting technological activities related to a given NR base and the ones fostering pervasive technologies, such as biotechnology, nanotechnology, bioelectronics/bioinformatics, new materials and ICTs. This is relevant because the efforts in the latter should also address the demands of the former.

Finally, bearing in mind that the accumulation of innovation capabilities may be lengthy, efforts to support diversification towards high-value added activities may require a longterm horizon. This approach should envisage gradual changes from $\underline{N R}$ production to resource-intensive manufacturing, all the way to knowledge-intensive manufacturing and service provision.

\section{* Initiatives to support the de- velopment of human capital}

Actions to increase and improve the supply of skilled human resources and create a critical mass of highlyqualified and competent managers, engineers, technicians and civil servants are necessary to meet innovation goals in NR sectors. 
It is important that the public education and training system provide human resources with appropriate skills and knowledge that meet the requirements of NR-related sectors, particularly in knowledge areas relevant to the current specialization profile of the economy.

This should be coupled by initiatives that stimulate firms' in-house training programs. Investment in higher education should give great emphasis to engineering and science disciplines in close alignment with the knowledge areas that are relevant for specific NR sectors, while post-graduate programs should contain a strong NR-oriented focus. A sector-oriented focus is also important for technical education programs.

* Initiatives to assist domestic firms in complying with IPR regulations and strengthen IPR protection of local efforts

It is important to consider carefully how important institutions such as IPR systems, regulations and public research are affecting and interacting with the innovation activities of local producers connected to NRs. In the seed sector, for instance, the costs to de-regulate a new technological event (genes) are ten times higher than the research activity leading to the introduction of the event.
It is so difficult and expensive to deregulate new events that there are numerous international companies dedicated to provide support to firms in deregulating new events in different markets.

Governments should provide this type of support for local producers that do not have the resources to obtain the services from international companies. In a similar vein, IPR systems have to be reviewed so that they provide protection to the innovations taking place domestically. In the seed industry, again, the more common innovations in the region take place by conventional breeding.

The new varieties obtained by classical breeding techniques cannot be patented. When local seed producers have to use a new gene, which can be patented, they have to pay a royalty. However, when an international company uses a local variety to implant genes, they own and sell it locally, they do not have to pay royalties to the local innovators of new varieties. These distortions have to be revised. 


\section{FGV}

EBAPE

\section{Acknowledgements}

We would like thank the International Research Development Centre (IDRC) for funding the research underlying this policy brief and Getulio Vargas Foundation (FGV) for the institutional, administrative and infrastructural support to this project. We are grateful to Dr. Isabel Bortagaray, program manager at IDRC, for supervising this project, and to the IDRC's administrative team, especially Helen Raij, Clara Saavedra, Barbara Miles and Shaun Bona for looking after this project. We are deeply grateful to Martin Bell, Professor Emeritus of SPRU - Science and Technology Research, University for Sussex, UK, for his role as Project Evaluator. By embedding in several activities of this project, he constantly provided us with critical, insightful and helpful feedbacks which proved essential for improving and enriching our analyses. Special thanks go to Gustavo Crespi, former IDRC's program manager, for his comments and constructive criticisms during the design and review of this project's proposal. We are grateful to research assistants Sergio Burdiles, Marcela Cohen, Saulo Gomes, Rafael Gonzalez, Yamila Kababe, and Sergio Petralia for their contribution to this project. We also acknowledge master students Christian Araya (Universidad de Chile) and Alexandre Matias (FGV) who have developed their theses within this project and the participation of FGV's undergraduate student, Gabriel Barreto. Our special thanks go to the professional of the organizations who participated in the fieldwork for this study. We are grateful to the Brazilian Institute of Geography and Statistics (IBGE) for their attention and support during the data collection and analysis. We thank the policy makers, corporate managers and researchers who participated in the workshops of this project in Rio de Janeiro and Buenos Aires. We are grateful to FGV/EBAPE, Universidad de Chile and Universidad San Andrés for providing us with superb facilities for the implementation of the four workshops of this project. All disclaimers apply.

\footnotetext{
${ }^{2}$ The Economist (2010). 'Can Russia create a new Silicon Valley?', July $14^{\text {th }}$, p. 58.

${ }^{3}$ Lederman, D. and Maloney, W. (2007) Natural Resources: Neither Curse nor Destiny. Stanford University Press and World Bank. Washington, D.C; De Ferranti, D., Perry, G., Lederman, D. and Maloney, W. (2002) From Natural Resources to the Knowledge Economy: Trade and Job Quality. Latin American and Caribbean Studies. World Bank, Washington, DC; de la Torre, A., Sinnott, E. and Nash, J. (2010) Natural resources in Latin America and the Caribbean: beyond booms and busts? The World Bank, Washington, DC.

${ }^{4}$ Perez, C. (2008). A Vision for Latin America: a Resource-Based Strategy for Technological Dynamism and Social Inclusion. Globelics Working Paper Series, No. WPG0804, (originally prepared for ECLAC).

${ }^{5}$ The Economist (2010). 'It's only natural: commodities alone are not enough to sustain flourishing economies'. Special report: Latin America. September $9^{\text {th }}: 3-6$.

${ }^{6}$ Prebisch, R. (1950). The economic development of Latin America and its principal problems. United Nations Dept. of Economic Affairs. New York

${ }^{7}$ Hirschman, A. (1958). Strategy of economic development. New Haven: Yale University Press.

${ }^{8}$ Sachs, J. and Warner A. (2001). The curse of natural resources. European Economic Review, 45 (4-6): 827-838.
} 


\section{FGV}

EBAPE

${ }^{9}$ Bravo Ortega C. and De Gregorio, J. (2005). The relative richness of the poor? Natural resources, human capital and economic growth". Policy Research Working Paper, Series 3484, The World Bank: Washington.

${ }^{10}$ Marin, A., Navas-Alemán, L. and Perez, C., (2009) 'The possible dynamic role of natural resource-based networks in Latin American development strategies'. Economic Commission for Latin America, ECLAC-SEGIB project document. Also presented at the GLOBELICS conference in 2010.

${ }^{11}$ Marin, A., Petralia, S. and Bravo-Ortega, C. (2012) Technological opportunities in natural resources-related industries in Latin America, Working Document. Research Programme on Technological Learning and Industrial Innovation in Brazil. FGV/EBAPE: Rio de Janeiro, 29pp

${ }^{12}$ Figueiredo, P., Dantas, E., Marin, A., Kababe, Y; Bravo-Ortega, C., Gomes, S., Gonzalez, R. and Cohen, M. (2012). Innovation capability building in biofuels: evidence from Argentina, Brazil and Chile, Working Document. Research Programme on Technological Learning and Industrial Innovation in Brazil. FGV/EBAPE: Rio de Janeiro, 68pp; Bravo-Ortega, C., Figueiredo, P., Marin, A. and Dantas, E. (2012). Innovation capability building in the forestry, pulp and paper, Working Document. Research Programme on Technological Learning and Industrial Innovation in Brazil. FGV/EBAPE: Rio de Janeiro, 90pp; Marin, A., Kababe, Y., Figueiredo, P., Bravo-Ortega, C. and Dantas, E. (2012). Using natural resource industries as a platform for the development of knowledge intensive industries in Latin America: the seed industry in Argentina, Brazil and Chile, Working Document. Research Programme on Technological Learning and Industrial Innovation in Brazil. FGV/EBAPE: Rio de Janeiro.

${ }^{13}$ For details see Figueiredo, Paulo N. (2010), Discontinuous innovation capability accumulation in latecomer natural resource-processing firms. Technological Forecasting \& Social Change, 77 (2): 1090-1108; and Figueiredo, Paulo N. (2011). Variability in Micro-level Innovation Performance in Natural Resource-processing. Industry Studies Association Working Paper Series, Pittsburg: University of Pittsburg.

${ }^{14}$ Hausmann, R. and Rodrik, D. (2003), Economic development as self-discovery, Journal of Development Economics, 72 (2): 603-633. 